Article

\title{
A Comparative Study on the Effect of Flotation Reagents on Growth and Iron Oxidation Activities of Leptospirillum ferrooxidans and Acidithiobacillus ferrooxidans
}

\author{
Mohammad Jafari ${ }^{1}$, Said Zia Aldin Shafaei ${ }^{1}$, Hadi Abdollahi ${ }^{1}$, Mahdi Gharabaghi ${ }^{1}$ \\ and Saeed Chehreh Chelgani ${ }^{2, *}$ \\ 1 School of Mining Engineering, University of Tehran, Tehran 16846-13114, Iran; \\ mo.jafari1664@gmail.com (M.J.); zshafaie@ut.ac.ir (S.Z.A.S.); h_abdollahi@ut.ac.ir (H.A.); \\ gharabaghi@ut.ac.ir (M.G.) \\ 2 Department of Electrical Engineering and Computer Science, University of Michigan, Ann Arbor, \\ MI 48109, USA \\ * Correspondence: schehreh@umich.edu; Tel.: +49-174-535-6532
}

Academic Editor: William Skinner

Received: 19 November 2016; Accepted: 26 December 2016; Published: 30 December 2016

\begin{abstract}
Recently, extraction of metals from different resources using a simple, efficient, and low-cost technique-known as bioleaching-has been widely considered, and has turned out to be an important global technology. Leptospirillum ferrooxidans and Acidithiobacillus (Thiobacillus) ferrooxidans are ubiquitous bacteria in the biomining industry. To date, the effects of commercial flotation reagents on the biooxidation activities of these bacteria have not been thoroughly studied. This investigation, by using various systematic measurement methods, studied the effects of various collectors and frothers (collectors: potassium amylxanthate, potassium isobutyl-xanthate, sodium ethylxanthate, potassium isopropylxanthate, and dithiophosphate; and frothers: pine oil and methyl isobutyl carbinol) on L. ferrooxidans and A. ferrooxidans activities. In general, results indicate that in the presence of these collectors and frothers, L. ferrooxidans is less sensitive than T. ferrooxidans. In addition, the inhibition effect of collectors on both bacteria is recommended in the following order: for the collectors, potassium isobutyl-xanthate $>$ dithiophosphate $>$ sodium ethylxanthate $>$ potassium isobutyl-xanthate > potassium amylxanthate; and for the frothers, methyl isobutyl carbinol > pine oil. These results can be used for the optimization of biometallurgical processes or in the early stage of a process design for selection of flotation reagents.
\end{abstract}

Keywords: flotation; collector; frother; bioleaching; Leptospirillum; Acidithiobacillus (Thiobacillus) ferrooxidans

\section{Introduction}

Reagents (collectors, frothers, etc.) play essential roles during mineral separation by flotation. The main purposes for addition of reagents into the process are providing the highest selectivity (grade) and concentration results (recovery). They react with the surface of the target minerals and-based on their properties—change the hydrophobicity of mineral surfaces (i.e., collectors and depressants), or reduce the surface tension of pulp by providing a large air-water interface (i.e., frothers). The residual of these reagents remains on the surface of products (concentrate and tail). Generally, flotation products (typically concentrates) are subjected to pyro-, hydro-, or biometallurgy process for the metal extraction. Although the presence of these residual surfactants on flotation products has no essential effect on the pyrometallurgical extractions [1], they may have 
significant impacts (positive or negative) on microbial activities involving in the biometallurgical metal extraction [2-5].

There are some investigations on the effect of flotation reagents in bioleaching technology that generally focused on their impacts over the metallurgical parameters (recovery and grade of products) [1,3,6-10], however, the fundamental effects of these chemicals on bacterial activities are not yet widely studied. It was reported that the recovery and grade in a bioleaching process of flotation products (in the presence of remaining surfactants) could be highly affected by type of reagents (their chemical compositions and structures), concentration of reagents, and type of microorganisms (various metabolisms, cellular membranes, strains, etc.) [1,3-8]. Among microorganisms, Acidithiobacillus ferrooxidans (A. ferrooxidans) was the first bacterium isolated from an acidic leaching environment for biomining, and it was used in many early bioleaching studies until Leptospirillum ferrooxidans (L. ferrooxidans) was found and it was reported that L.ferrooxidans can be the dominant iron-oxidizing bacteria in biomining processes $[2,9,11-16]$. The negative effect of different collectors and frothers on A. ferrooxidans activity was observed in various investigations $[3,7]$. Dehghan and Dianati (2015) reported the positive effect of potassium amylxanthate and potassium ethylxanthate on both $A$. ferrooxidans and L. ferrooxidans. The solubility of elemental sulfur as a passivation layer on the mineral surfaces was reported as a potential reason for such a positive effect [1].

In the early stage of designing a flotation process and selecting reagents, the major advances would be the metallurgical parameters of final products. A systematic investigation on the effects of commercial surfactants on microbial activities can be a key to: (1) better understand the mechanisms of reactions and (2) efficiently select reagents when, in the downstream, flotation products are going to be processed by bioleaching for extraction of metals. In this study, to extensively realize possible interactions of industrial surfactants on biooxidation, the influence of various conventional reagents for flotation of sulfides (collectors: potassium amylxanthate (KAX), potassium isobutyl-xanthate (KIBX), sodium ethylxanthate ( $\mathrm{NaEX}$ ), potassium isopropylxanthate (KIPX), and dithiophosphate (Aero3477); and frothers: pine oil (PO) and methyl isobutyl carbinol (MIBC)) on L. ferrooxidans and A. ferrooxidans activities were compared by fundamental measurements ( $\mathrm{pH}$, oxidation-reduction potential (ORP), dissolved oxygen $\left(\mathrm{DO}_{2}\right)$, microorganisms counting method, and iron ion $\left(\mathrm{Fe}_{\mathrm{T}}\right.$ (iron total), $\mathrm{Fe}^{2+}$, and $\mathrm{Fe}^{3+}$ ) analyses. The output of this work can be applied for the optimization and selection of bacteria and flotation reagents in mineral-processing plants.

\section{Materials and Methods}

Sixteen tests were designed ( 2 control tests without reagents, and 14 tests with the seven different reagents for the two bacterial species, L. ferrooxidans and A. ferrooxidans. Tests were performed in a $250 \mathrm{~mL}$ Erlenmeyer flask at $34{ }^{\circ} \mathrm{C}$ and agitated in an orbital incubator shaker (model: Wisecube) at $140 \mathrm{rpm}$. Glassware and $\mathrm{pH}$ electrodes were rinsed in $98 \%$ ethanol and distillated water to avoid contamination, and then they were dried [17].

\subsection{Microorganism and Culture Conditions}

Pure strains of L. ferrooxidans and A. ferrooxidans (prepared from the Center of Research and Development of the Sarcheshmeh Mine, Kerman, Iran) were separately cultured in $85 \mathrm{~mL} 9 \mathrm{~K}$ medium containing $44.22 \mathrm{~g} / \mathrm{L} \mathrm{FeSO} 4 \cdot 7 \mathrm{H}_{2} \mathrm{O}$ as a source of energy $(10.0 \mathrm{~g} / \mathrm{L}$ sulfur was also added to the culture of $A$. ferrooxidans) [18]. The $9 \mathrm{~K}$ medium - the growth medium for the bacteria-contained five different mineral salts $\left(\left(\mathrm{NH}_{4}\right)_{2} \mathrm{SO}_{4}: 3.0 \mathrm{~g} / \mathrm{L}, \mathrm{MgSO}_{4} \cdot 7 \mathrm{H}_{2} \mathrm{O}: 0.5 \mathrm{~g} / \mathrm{L}, \mathrm{K}_{2} \mathrm{HPO}_{4}: 0.5 \mathrm{~g} / \mathrm{L}, \mathrm{KCL}: 0.1 \mathrm{~g} / \mathrm{L}\right.$, and $\left.\mathrm{Ca}\left(\mathrm{NO}_{3}\right)_{2} \cdot \mathrm{H}_{2} \mathrm{O}: 0.01 \mathrm{~g} / \mathrm{L}\right)$.

\subsection{Flotation Reagents}

The pure reagents (collectors: KAX, KIBX, NaEX, KIPX and Aero3477; and PO and MIBC) were provided by the Mineral Processing Laboratory at the University of Tehran, Iran. To better compare 
the effects of these reagents on bacterial activities and avoid the effect of reagent concentrations, a constant dosage of $0.01 \% w / v$ (the industrial dosage in the Sarcheshmeh plant) has been selected for the all surfactants.

\subsection{Analytical Procedures}

The effectiveness of reagents on bacterial activities was explored by the differences of test results to their control test $(\Delta$ variable $=$ Value in the presence of reagent - Value of the control test; based on the day of measurements). The initial $\mathrm{pH}$ of culture was adjusted to $1.8 \mathrm{by}_{2} \mathrm{SO}_{4}$. The $\mathrm{pH}$ and ORP value were measured by $\mathrm{pH} / \mathrm{ORP}$ analyzer (Mettler Toledo) on various days. The amount of dissolved oxygen $\left(\mathrm{DO}_{2}\right)$ in the media was determined by an oxygen meter (model JENWAY). The bacterial population $(\mathrm{N})$ was counted by using a Neubauer lamp $\left(0.1 \times 1 / 400 \mathrm{~mm}^{2}\right)(\mathrm{HBG}$, Giessen, Germany) and 100 $\times$ magnification under a Zeiss biological microscope (Bacterial count per $\mathrm{mL}=\mathrm{N} \times 400 \times 10^{4}$ ) (Zeiss: Carl Zeiss AG, Oberkochen, Germany). The variation of $\mathrm{Fe}_{\mathrm{T}}$ was monitored by an atomic adsorption spectrophotometer (AAS model: varian-20). The amount of $\mathrm{Fe}^{2+}$ was determined via titration by dichromate potassium $(0.001 \mathrm{M})$ in the presence of $\mathrm{H}_{2} \mathrm{SO}_{4}: \mathrm{H}_{3} \mathrm{PO}_{4}$ solution (1:1) with diphenylamine as an indicator [19-21]. $\mathrm{Fe}^{3+}$ percentage was calculated by subtracting $\mathrm{Fe}^{2+}$ from $\mathrm{Fe}_{\mathrm{T}}$ $\left(\mathrm{Fe}_{\mathrm{T}}=\mathrm{Fe}^{2+}+\mathrm{Fe}^{3+}\right)[19]$. The $\frac{\mathrm{Fe}^{3+}}{\mathrm{Fe}^{2+}}$ ratio was used to define the effects of reagents on L. ferrooxidans and A. ferrooxidans oxidizing activities.

\section{Results and Discussion}

\subsection{Subsection}

The deviation of $\mathrm{pH}$ from the control test $\left(\Delta_{\mathrm{pH}}\right)$ in the presence of various collectors (Figure 1a-e) shows increases in the $\Delta_{\mathrm{pH}}$ during the first 2 days of L. ferrooxidans and A. ferrooxidans activities in all tests $\left(+\Delta_{\mathrm{pH}}\right)$. These increases are higher in the presence of L. ferrooxidans than in A. ferrooxidans tests (except in the presence of KIBX and KIPX) (Figure 1c,d). The instability of these collectors when $\mathrm{pH}<3$ could be an explanation for these increases, where the $\mathrm{pH}$ may increase as a result of the $\mathrm{H}^{+}$ consumption from the solution for the decomposition of the collectors in the early stage of experiments (Equations (1) and (2)) [7,22-24]. During the next 14 days, the $\Delta_{\mathrm{pH}}$ decreased in all experiments. Reduction of $\mathrm{Fe}^{3+}$ to $\mathrm{Fe}^{2+}$ can lead to the decrease in $\mathrm{pH}$ values of the solution (Equation (3)) [1,25-29]. KIPX shows the highest $\mathrm{pH}$ reduction in the A. ferrooxidans test $\left(-\Delta_{\mathrm{pH}}\right)$ (Figure 1d).

$$
\begin{gathered}
\mathrm{RX}^{-}+\mathrm{H}^{+} \rightarrow \mathrm{RXH} \\
\mathrm{RXH} \rightarrow \mathrm{ROH}+\mathrm{CS}_{2} \\
\mathrm{Fe}^{3+}+6 \mathrm{H}_{2} \mathrm{O} \rightarrow 2 \mathrm{Fe}(\mathrm{OH})_{3}+2 \mathrm{H}^{+}
\end{gathered}
$$

During the next 14 days, in the presence of all collectors the $\mathrm{pH}$ for the L. ferrooxidans test gradually decreased (KAX shows the highest rate of $\mathrm{pH}$ reduction (Figure $1 \mathrm{~b}$ )). This phenomenon indicates that L. ferrooxidans bacteria, during 21 days, steadily adjusts to the test conditions ( $-\Delta_{\mathrm{pH}}$ at day 21 for Aero, $\mathrm{KAX}$, and KIPX), while the $\Delta_{\mathrm{pH}}$ for the $A$. ferrooxidans tests shows variations in different conditions. After 7 days, for the A. ferrooxidans tests in the presence of NaEX and KAX (higher than the control test; $\left.+\Delta_{\mathrm{pH}}\right)$ and KIPX $\left(-\Delta_{\mathrm{pH}}\right)$, the $\Delta_{\mathrm{pH}}$ increased (Figure 1a,b,d), whereas in the presence of KIBX and Aero, after 14 days the $\Delta_{\mathrm{pH}}$ increased (Figure 1c,e). One of the main reasons for these differences between L. ferrooxidans and A. ferrooxidans can be attributed to the fact that, in contrast to A. ferrooxidans, L. ferrooxidans can oxidize $\mathrm{Fe}^{2+}$ even at $\mathrm{pH}$ below $1.2[15,28,30]$. Previous studies indicated that L. ferrooxidans is more resistant to low $\mathrm{pH}$ than $A$. ferrooxidans and can grow at a $\mathrm{pH}$ as low as 1.2 (the optimum $\mathrm{pH}$ range for the growth of $A$. ferrooxidans is 1.8-2.5) [15,31-33]. In general, the negative effect of reagents on $A$. ferrooxidans and $L$. ferrooxidans has the following order: NaEX $>$ KAX $>$ KIBX $>$ Aero $>$ KIPX and KIBX > NaEX > Aero $>$ KIPX > KAX, respectively. For the frothers (Figure 1f,g), 
in case of $A$. ferrooxidans the trend for both frothers is the same; after 7 days, the $\mathrm{pH}$ of the tests was lower than that of the control test $\left(-\Delta_{\mathrm{pH}}\right)$, after which it increases until day 21 when it significantly decreases. In the presence of $L$. ferrooxidans, the $\mathrm{pH}$ was continually higher than that of the control test $\left(+\Delta_{\mathrm{pH}}\right)$ during 21 days in the presence of both MIBC and PO. The inhibition order for both bacteria in the presence of two frothers shows the following order: MIBC $>$ PO.
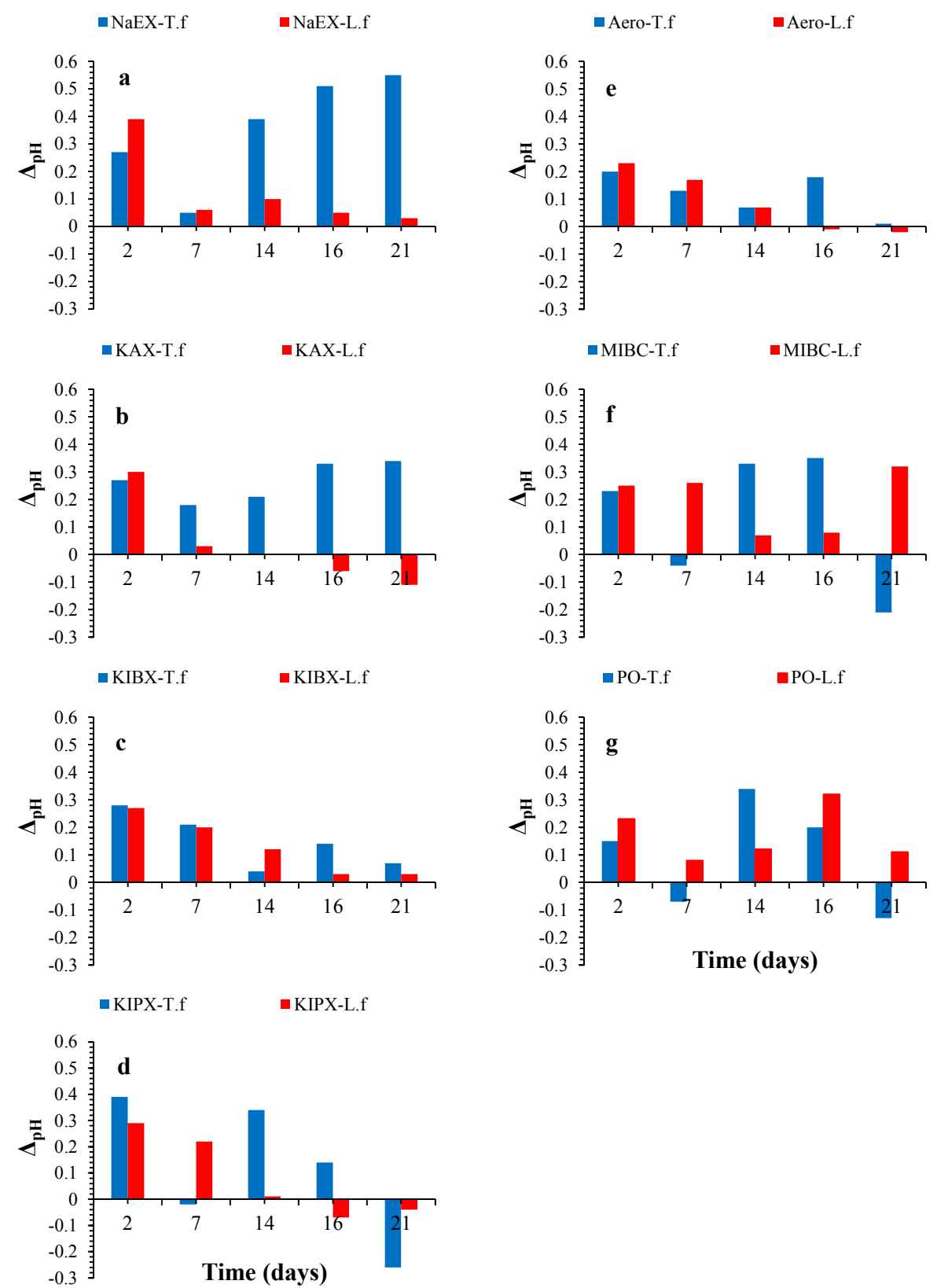

Figure 1. Effects of various flotation reagents on $\mathrm{pH}$ during L. ferrooxidans and A. ferrooxidans activities.

\subsection{ORP Variations}

The ORP analyses of all tests (Figure $2 \mathrm{a}-\mathrm{g}$ ) indicate that during the first 2 days there was low deviation in the ORP value from the control test $\left(\sim \Delta_{\mathrm{ORP}}=0\right)$. Within the next 19 days, as the reactions proceeded and activity of $L$. ferrooxidans increased, an increase in the ORP value is observed in the presence of all collectors $\left(+\Delta_{\mathrm{ORP}}\right)$ (except Aero), and $\Delta_{\mathrm{ORP}}$ in L. ferrooxidans tests is continuously positive within 21 days. In the $A$. ferrooxidans tests, $\Delta_{\mathrm{ORP}}$ is positive for KAX, KIBX, and Aero (Figure $2 b, c, e$ ), and it is constantly negative for KIPX and NaEX (Figure 2a,d). The ORP increases 
can be explained by the biooxidation and regeneration of $\mathrm{Fe}^{3+}$ to $\mathrm{Fe}^{2+}$, and the differences between bacteria performances can be interpreted by the fact that $L$. ferrooxidans has a lower maximum specific utilization rate than $A$. ferrooxidans at low ORP, and can intersect at a high ORP. In other words, L. ferrooxidans species have capability to withstand extreme conditions, such as a quite high ORP value [15]. Generally, the deviation of the ORP value from the control test $\left(\Delta_{\mathrm{ORP}}\right)$ in the presence of collectors for A. ferrooxidans and L. ferrooxidans can be described in the following order: NaEX $>$ KIPX > Aero $>\mathrm{KAX}>\mathrm{KIBX}$ and Aero $>\mathrm{KIPX}>\mathrm{KIBX}>\mathrm{NaEX}>\mathrm{KAX}$, respectively. For both frothers, $\Delta_{\mathrm{ORP}}$ is continuously negative for $L$. ferrooxidans tests during 21 days, and the $\mathrm{PO}$ in the A. ferrooxidans tests shows higher ORP than the control test $\left(+\Delta_{\mathrm{ORP}}\right)$ within the last 5 days of measurements (Figure $2 \mathrm{f}, \mathrm{g}$ ). $\triangle_{\text {ORP }}$ shows that MIBC has a higher inhibition effect than PO on both microorganisms.
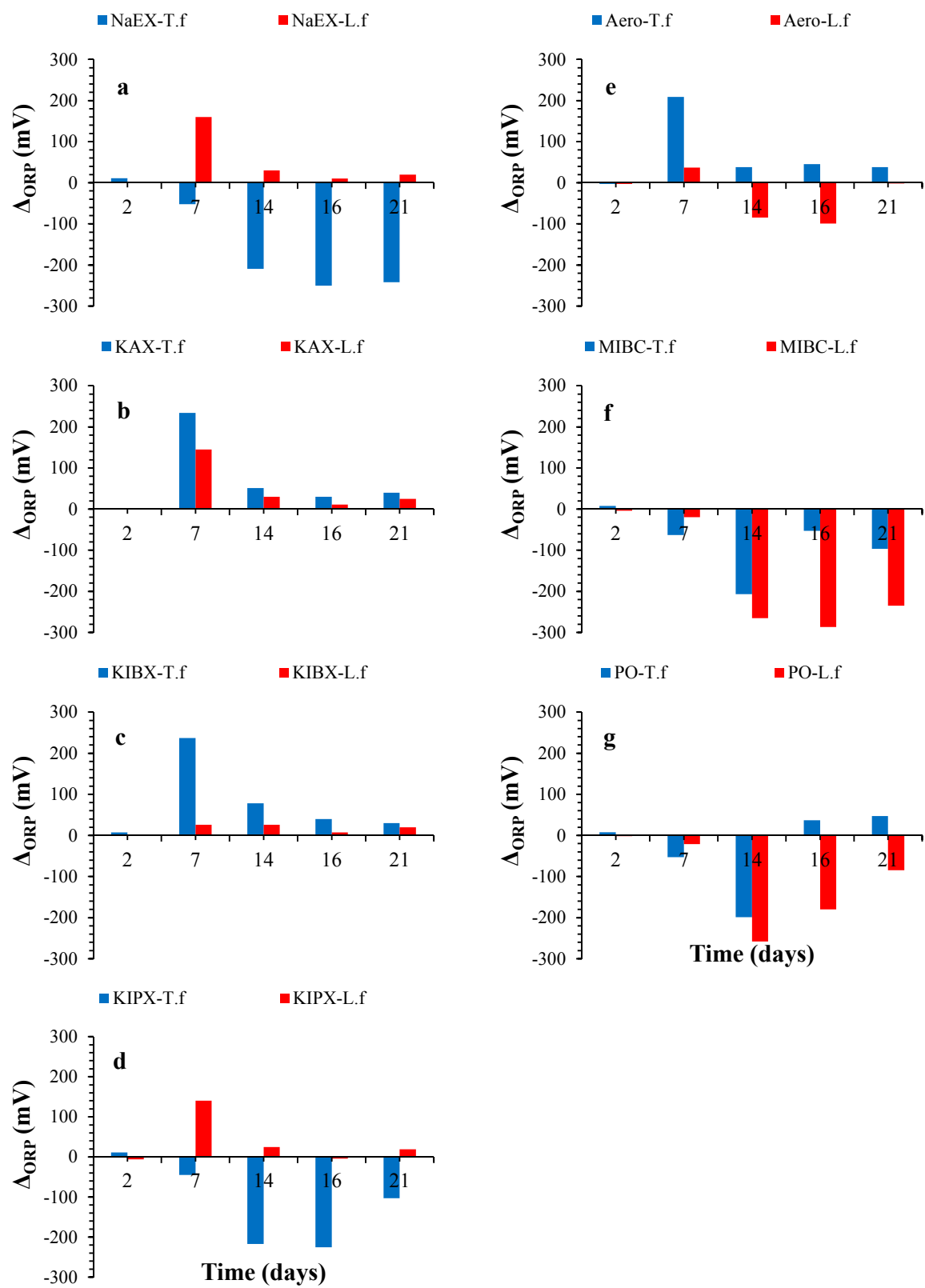

Figure 2. Effects of various flotation reagents on ORP during L. ferrooxidans and T. ferrooxidans activities. 


\section{3. $\mathrm{DO}_{2}$ Variation}

Oxygen species in the culture play a critical role for the bacteria to complete their cycle of respiration [34,35]. Within the initial day, $\Delta_{\mathrm{DO}_{2}}$ for the L. ferrooxidans tests in the presence of $\mathrm{NaEX}$, $\mathrm{KAX}$, and KIBX is positive, and for Aero and KIPX it is negative. $\Delta_{\mathrm{DO}_{2}}$ gradually decreases to be less than or close to the control test at day 21 for all collectors (Figure 3a-e). For A. ferrooxidans tests, $\Delta_{\mathrm{DO}_{2}}$ is negative in all collectors (except KAX), and during next 7 days the value reaches the control tests in all collectors (except Aero). During the measurement, until day 21, $\mathrm{DO}_{2}$ values remain lower than the $\mathrm{DO}_{2}$ value of the control test $\left(-\Delta_{\mathrm{DO}_{2}}\right)$ for $A$. ferrooxidans tests except for $\mathrm{NaEX}$ and KAX, which show the highest positive deviations (Figure $3 \mathrm{a}, \mathrm{b}$ ). The presence of unstable collectors in the low $\mathrm{pH}$ culture can limit the availability (i.e., transfer) of oxygen (xanthates are unstable in acidic solutions, and their instabilities increase by decreasing the $\mathrm{pH}[7,22-24])$. These reactions' inhibitory effect increase the $\mathrm{DO}_{2}$ value [36-38]. Thus, a decrease in the $\mathrm{DO}_{2}$ value shows a positive effect of reagents on activities of microorganisms. During the process, the $\mathrm{DO}_{2}$ deviation from the control test in the presence of collectors had the following order for A. ferrooxidans and L. ferrooxidans: KIPX $>$ KIBX $>$ Aero $>$ NaEX $>$ KAX and KIPX $>$ Aero $>$ NaEX $>$ KAX $>$ KIBX, respectively. For both frothers and in the presence of both microorganisms, after the first day, $\Delta_{\mathrm{DO}_{2}}$ is constantly negative. These negative values are the highest in the presence of MIBC at day 21 and of PO at day 8 for both bacteria. Results indicate that $\mathrm{PO}$ is more inhibitive than MIBC on the transfer of oxygen into the culture for A. ferrooxidans; and for L. ferrooxidans, MIBC > PO (Figure 3f-g).
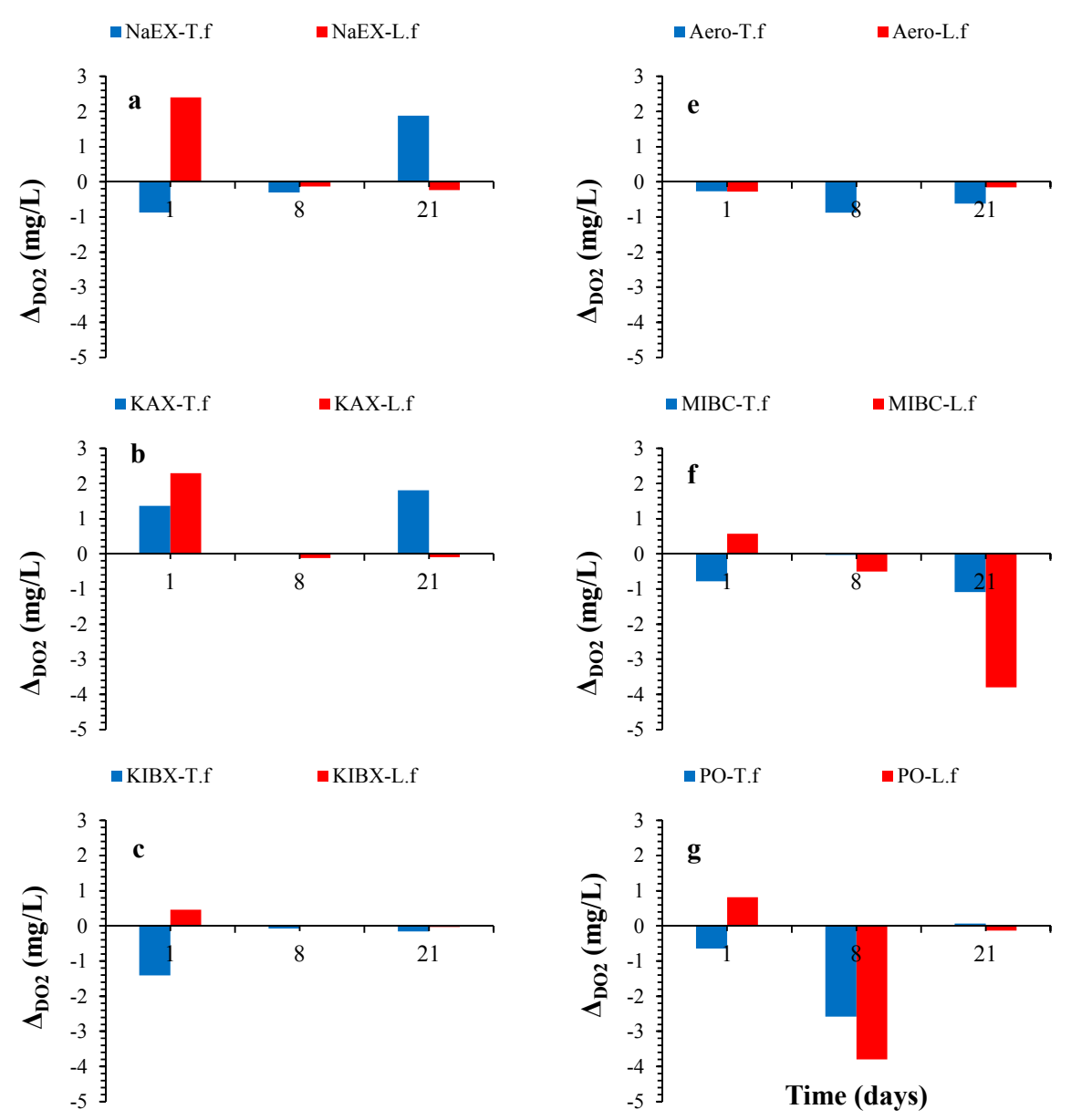

Figure 3. Cont. 


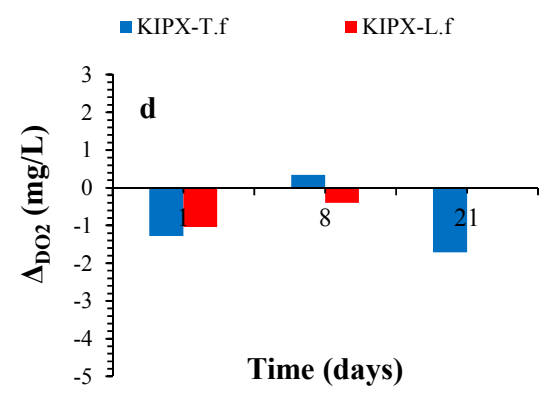

Figure 3. Effects of various flotation reagents on dissolved oxygen during L. ferrooxidans and T. ferrooxidans activities.

\subsection{Microorganism Population}

During the first 8 days of the process, the L. ferrooxidans population is constantly higher than the control test $\left(+\Delta_{\text {Count }}\right)$ in the presence of all collectors (Figure $\left.4 \mathrm{a}-\mathrm{e}\right)$, while for $A$. ferrooxidans, $\Delta_{\text {Count }}$ is positive just in the presence of Aero and KAX (Figure $4 \mathrm{~b}, \mathrm{e}$ ). Within next days, for all collectors the population of both bacteria progressively decreases to less than the control test $\left(-\Delta_{\text {Count }}\right)$. For both L. ferrooxidans and $A$. ferrooxidans, NaEX and KIPX show the highest deviation $\left(-\Delta_{\text {Count }}\right)$ from the control test (Figure 4a,d), which is in good agreement with the ORP results (Figure 2a,d). In general, results show that the inhibition effect of collectors is higher on A. ferrooxidans cell numbers than on the L. ferrooxidans population (in agreement with $\mathrm{pH}$ result (Figure 1a-e)). These results can explain the observed dominance of $L$. ferrooxidans over $A$. ferrooxidans during the process; although it was reported that at $30^{\circ} \mathrm{C}$, the growth rate of L. ferrooxidans is slower-it is about half of A. ferrooxidans [15] (in this study and in the control test after 21 days, $3.2 \times 10^{7}$ vs. $5.6 \times 10^{7}$ cells $/ \mathrm{mL}$ for L. ferrooxidans and A. ferrooxidans, respectively) - the growth of $L$. ferrooxidans is favored compared to A.ferrooxidans in an environment with a $\mathrm{pH}$ lower than $1.2[15,33,39]$. In general, the negative effect of collectors on A. ferrooxidans and L. ferrooxidans cell numbers has the following order: NaEX $>$ KIPX $>$ KIBX $>$ KAX $>$ Aero and KIPX $>\mathrm{KAX}>\mathrm{NaEX}>$ Aero $>\mathrm{KIBX}$, respectively. For both frothers, the $\Delta_{\text {Count }}$ is negative in the presence of microorganisms (Figure $4 \mathrm{f}, \mathrm{g}$ ). This negative effect in the presence of MIBC is higher than PO.
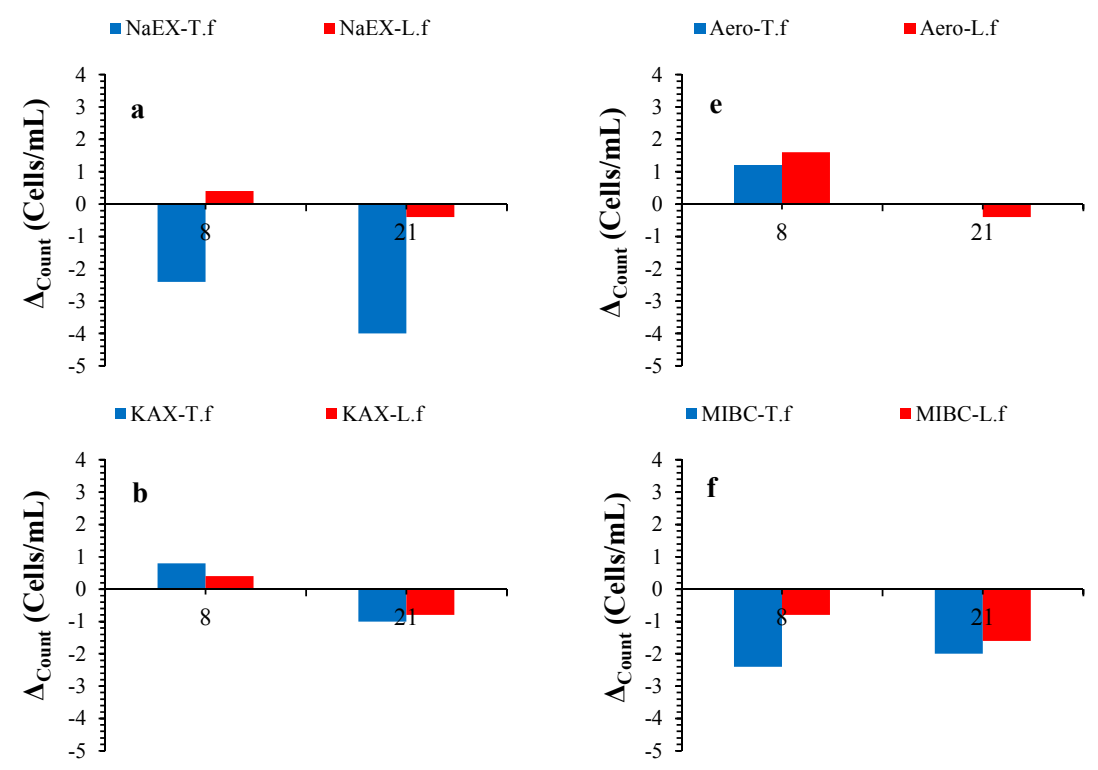

Figure 4. Cont. 

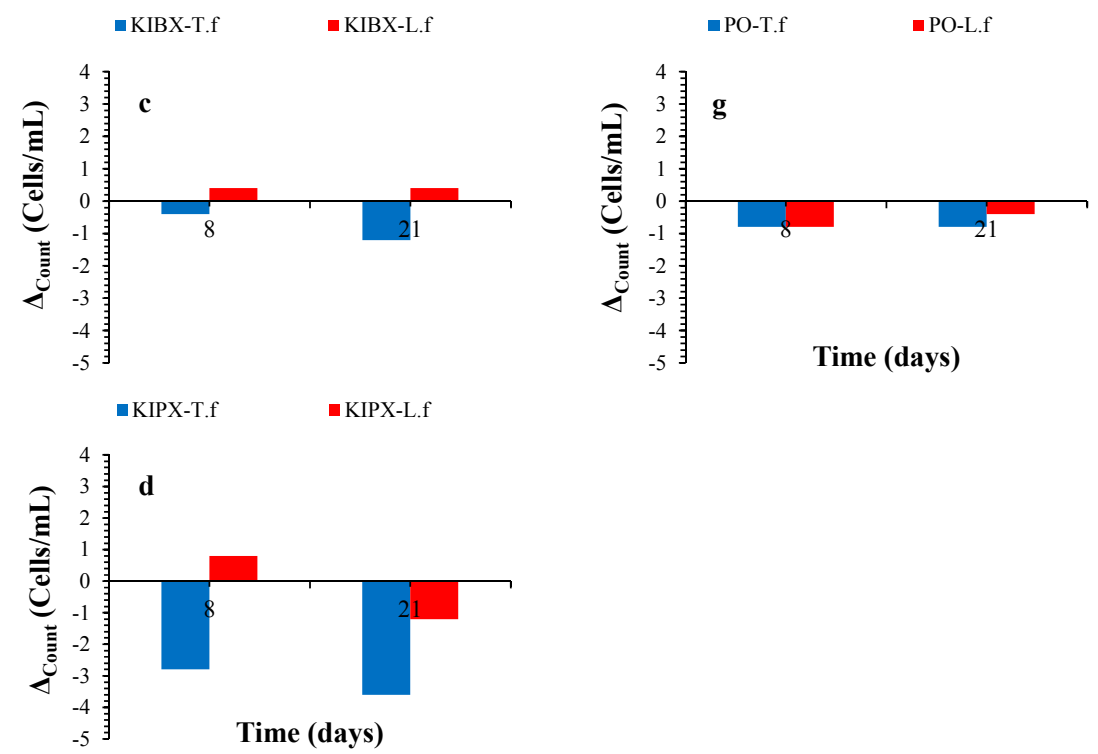

Figure 4. Effects of various flotation reagents on bacterial population during L. ferrooxidans and T. ferrooxidans activities.

\subsection{Fe Variation}

Results of $\mathrm{Fe}_{\mathrm{T}}$ measurement for L. ferrooxidans tests within 21 days of the procedure (Figure $5 \mathrm{a}-\mathrm{e}$ ) show that $\Delta_{\mathrm{Fe}_{\mathrm{T}}}$ is continuously negative, except in the presence of KIBX, which gradually increases until the last day of measurements (Figure 5c). During the process, the $\mathrm{Fe}_{\mathrm{T}}$ value for L. ferrooxidans tests in the presence of all collectors is approximately around the value of control test $\left(\Delta_{\mathrm{Fe}_{\mathrm{T}}} \simeq 0\right)$. In A. ferrooxidans tests, during interactions, $\Delta_{\mathrm{Fe}_{\mathrm{T}}}$ is negative for $\mathrm{KAX}, \mathrm{KIBX}$, and Aero (Figure $5 \mathrm{~b}, \mathrm{c}, \mathrm{e}$ ), and it is constantly positive for KIPX and NaEX (Figure $5 \mathrm{a}$,d). These results are in good agreement with the ORP and microorganism counting results (Figures 2 and 4). Lower $\mathrm{Fe}_{\mathrm{T}}$ than the control test $\left(-\Delta_{\mathrm{Fe}_{\mathrm{T}}}\right)$ in the presence of collectors can be described by their inhibition effects, as they lead to the precipitation of jarosite and other ferric oxides and hydroxides (Equations (4)-(6)). Jarosite precipitation is perceived as an unwanted interaction [40]. On the other hands, the positive value of $\Delta_{\mathrm{Fe}_{\mathrm{T}}}$ may be explained by the positive effect of reagents on the biooxidation activities, which can decrease the precipitation of iron into the medium.

$$
\begin{gathered}
\mathrm{Fe}^{3+}+2 \mathrm{H}_{2} \mathrm{O} \rightarrow \mathrm{FeOOH} \downarrow+3 \mathrm{H}^{+} \\
\mathrm{Fe}^{3+}+3 \mathrm{H}_{2} \mathrm{O} \rightarrow \mathrm{Fe}(\mathrm{OH})_{3} \downarrow+3 \mathrm{H}^{+} \\
3 \mathrm{Fe}^{3+}+\mathrm{M}^{+}+2 \mathrm{HSO}_{4}^{-}+6 \mathrm{H}_{2} \mathrm{O} \rightarrow \mathrm{MFe}_{3}\left(\mathrm{SO}_{4}\right)_{2}(\mathrm{OH})_{6} \downarrow+8 \mathrm{H}^{+}
\end{gathered}
$$

where $\mathrm{M}$ can be $\mathrm{K}, \mathrm{Na}, \mathrm{H}_{3} \mathrm{O}$, and $\mathrm{NH}_{4}$.
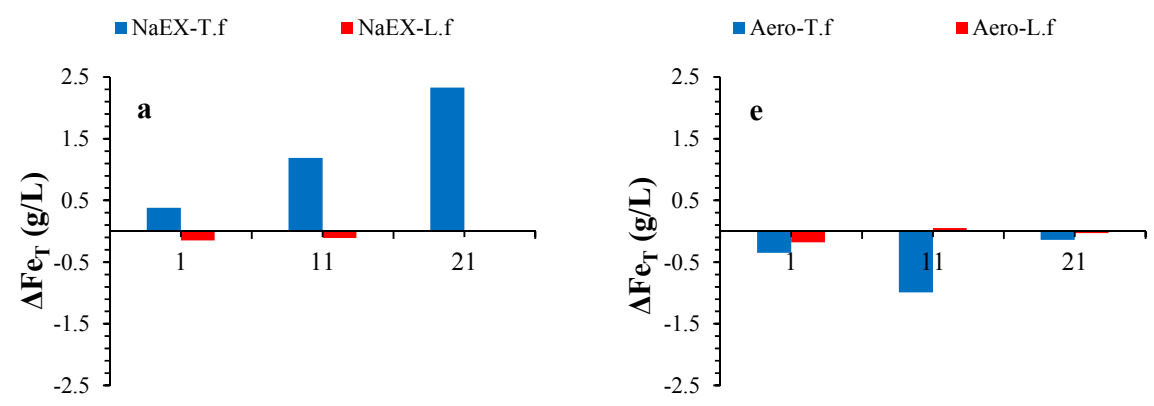

Figure 5. Cont. 


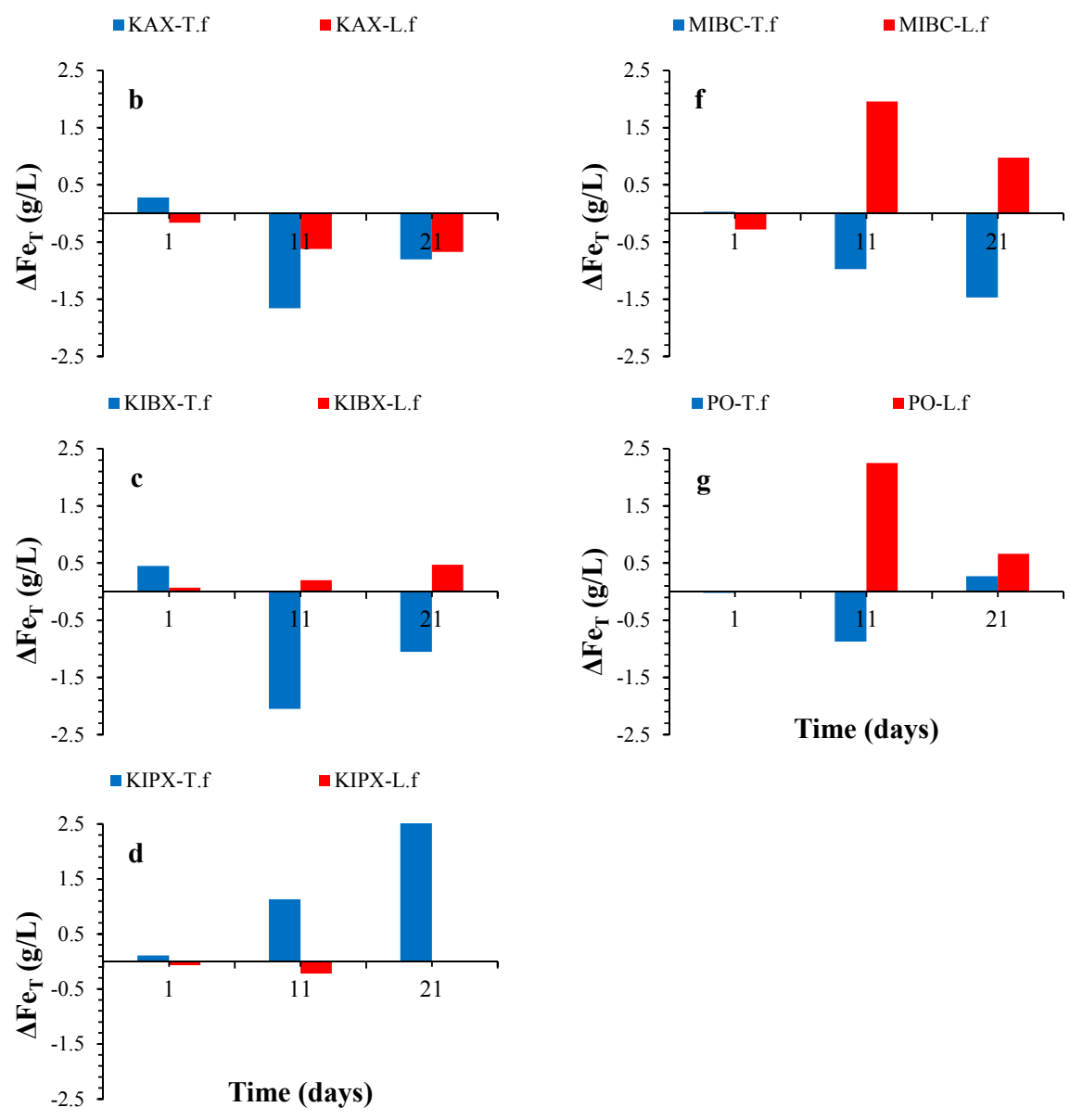

Figure 5. Effects of various flotation reagents on $\mathrm{Fe}_{\mathrm{T}}$ during L. ferrooxidans and A. ferrooxidans activities.

The $\frac{\mathrm{Fe}^{3+}}{\mathrm{Fe}^{2+}}$ ratio results for L. ferrooxidans tests in the existence of all collectors (Figure 6a-e) show that this ratio gradually increases during the process $\left(+\Delta \frac{\mathrm{Fe}^{3+}}{\mathrm{Fe}^{2+}}\right)$, except in the presence of $\mathrm{KAX}$, which remains less than the control test $\left(-\Delta \frac{\mathrm{Fe}^{3+}}{\mathrm{Fe}^{2+}}\right)$ (Figure 6b). In contrast to L. ferrooxidans, this ratio for $A$. ferrooxidans tests in the presence of all collectors steadily decreases to less than the control test $\left(-\Delta \frac{\mathrm{Fe}^{3+}}{\mathrm{Fe}^{2+}}\right)$ throughout the 21-day interactions (except for $\mathrm{KAX}$, whose $\Delta \frac{\mathrm{Fe}^{3+}}{\mathrm{Fe}^{2+}}$ is positive) (Figure 6b). In the presence of the both frothers, $\Delta \frac{\mathrm{Fe}^{3+}}{\mathrm{Fe}^{2+}}$ was negative for both bacteria during first 11 days. For L. ferrooxidans, the $\Delta \frac{\mathrm{Fe}^{3+}}{\mathrm{Fe}^{2+}}$ increases after day 11 and becomes positive. The rate of this increase is higher for MIBC than PO (Figure 6f,g). The following orders show the approximate inhibition effect of various collectors on the $\frac{\mathrm{Fe}^{3+}}{\mathrm{Fe}^{2+}}$ ratio for A. ferrooxidans and L. ferrooxidans: $\mathrm{NaEX}>$ $\mathrm{KIPX}>$ Aero $>\mathrm{KIBX}>\mathrm{KAX}$ and KAX $>$ Aero $>\mathrm{KIBX}>\mathrm{KIPX}>\mathrm{NaEX}$, respectively. For the frothers, it is $\mathrm{MIBC}>\mathrm{PO}$ for A. ferrooxidans, and $\mathrm{PO}>\mathrm{MIBC}$ for L. ferrooxidans. The growth of bacterial population increases the biooxidation of $\mathrm{Fe}^{2+}$ into $\mathrm{Fe}^{3+}$ ions (the increase of $\frac{\mathrm{Fe}^{3+}}{\mathrm{Fe}^{2+}}$ ratio). Interactions in the solution (biooxidation, dissolution of reagents, etc.) deteriorate the culture step-by-step for both L. ferrooxidans and A. ferrooxidans. An increase in the bacterial products, such as the $\frac{\mathrm{Fe}^{3+}}{\mathrm{Fe}^{2+}}$ ratio, can improve this deterioration [41]. It was reported that L. ferrooxidans is resistant to a $500 \mathrm{mM} \mathrm{Fe}{ }^{3+}$ concentration, whereas the growth of $A$. ferrooxidans is limited above a $36 \mathrm{mM} \mathrm{Fe}^{3+}$ dosage [42]. 

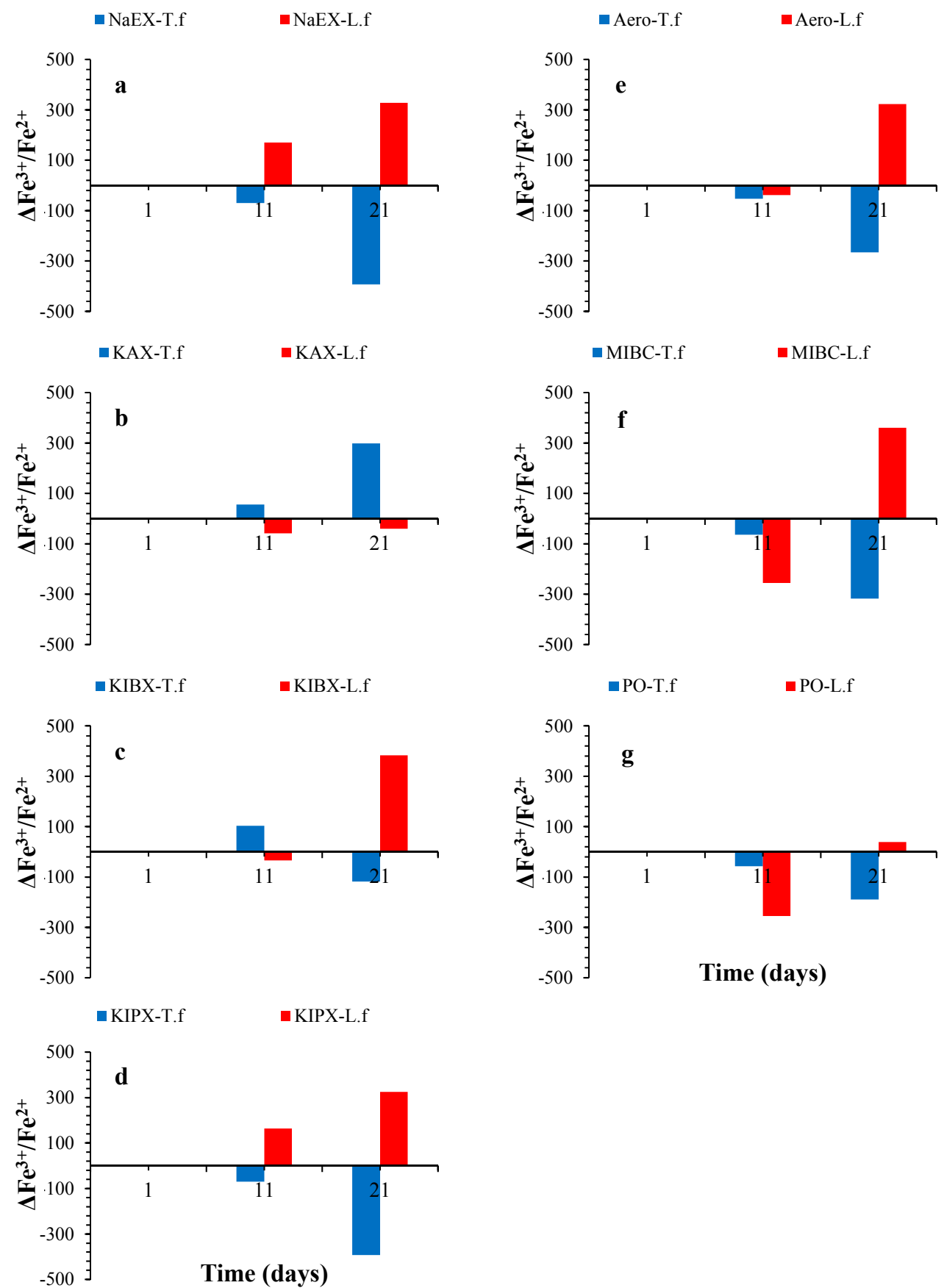

Figure 6. Effects of various flotation reagents on $\frac{\mathrm{Fe}^{3+}}{\mathrm{Fe}^{2+}}$ ratio during L. ferrooxidans and A. ferrooxidans activities.

In other words, $\mathrm{Fe}^{2+}$ oxidation by L. ferrooxidans is significantly less sensitive to end-product inhibition by $\mathrm{Fe}^{3+}(38 \mathrm{mM})$ than A. ferrooxidans $(2.5 \mathrm{mM})$, and L. ferrooxidans is able to oxidize $\mathrm{Fe}^{2+}$ into $\mathrm{Fe}^{3+}$ ions even at low oxygen concentrations [43]. Therefore, when the quantity of $\mathrm{Fe}^{3+}$ in solution is high, L. ferrooxidans will have a significant selective advantage over $A$. ferrooxidans [15]. In the initial days of the process, the $\frac{\mathrm{Fe}^{3+}}{\mathrm{Fe}^{2+}}$ ratio is low, which enables $A$. ferrooxidans to grow a large numbers of cells (before conditions become more favorable for L. ferrooxidans). Nevertheless, L. ferrooxidans has a higher attraction to $\mathrm{Fe}^{2+}$ and is less sensitive to inhibition by $\mathrm{Fe}^{3+}$ on prolonged aeration, which likely makes L. ferrooxidans dominate [44]. 
Taking all abovementioned results into consideration, it can be demonstrated that the flotation reagents-based on the type of microorganisms in the process-may have positive or negative effects on the biooxidation. Results show organic compounds such as flotation reagents have stronger inhibition effects on biooxidation activities of $A$. ferrooxidans versus L. ferrooxidans (KIBX approximately shows positive effects on $L$. ferrooxidans activities). In general, based on various analyses, the negative effects of collectors on A. ferrooxidans and L. ferrooxidans have the following orders: NaEX $>$ KIPX $>$ Aero $>$ KIBX $>$ KAX and KIPX $>$ KAX $>$ NaEX $>$ Aero $>$ KIBX, respectively. Moreover, the possible inhibition of these reagents shown by various measurements (Table 1) can be deduced to be in the following order for the both bacteria: KIPX $>$ Aero $>$ NaEX $>$ KIBX $>$ KAX. Results (Table 1) indicate that MIBC would contribute to higher toxicity than that of $\mathrm{PO}$ for the bacterial activities in $0.01 \% w / v$ dosage of these frothers.

Table 1. The order of negative effects of flotation reagents on biooxidation of both Acidithiobacillus ferrooxidans and Leptospirillum ferrooxidans activities.

\begin{tabular}{ccc}
\hline Parameters & \multicolumn{1}{c}{ Collectors } & Frothers \\
\hline $\mathrm{pH}$ & $\mathrm{NaEX}>\mathrm{KIBX}>\mathrm{KAX}>$ Aero $>$ KIPX & $\mathrm{MIBC}>\mathrm{PO}$ \\
$\mathrm{ORP}$ & $\mathrm{KIPX}>$ Aero $>\mathrm{NaEX}>\mathrm{KIBX}>\mathrm{KAX}$ & $\mathrm{MIBC}>\mathrm{PO}$ \\
$\mathrm{DO}_{2}$ & $\mathrm{KIPX}>$ Aero $>\mathrm{KIBX}>\mathrm{NaEX}>\mathrm{KAX}$ & $\mathrm{MIBC} \geq \mathrm{PO}$ \\
$\mathrm{Count}$ & $\mathrm{KIPX}>\mathrm{NaEX}>\mathrm{KAX}>\mathrm{KIBX}>$ Aero & $\mathrm{MIBC}>\mathrm{PO}$ \\
$\mathrm{Fe}_{\mathrm{T}}$ & $\mathrm{KAX}>\mathrm{KIPX}>\mathrm{KIBX}>$ Aero $>$ NaEX & $\mathrm{MIBC} \geq \mathrm{PO}$ \\
$\mathrm{Fe}^{3+}$ & Aero $>\mathrm{KIPX}>\mathrm{NaEX} \geq \mathrm{KAX}>\mathrm{KIBX}$ & $\mathrm{MIBC} \geq \mathrm{PO}$ \\
$\mathrm{Fe}^{2+}$ & & \\
\hline
\end{tabular}

ORP: oxidation-reduction potential; $\mathrm{DO}_{2}$ : dissolved oxygen; $\mathrm{Fe}_{\mathrm{T}}$ : total iron.

\section{Conclusions}

L. ferrooxidans and A. ferrooxidans are typical iron-oxidizing bacteria under highly acidic conditions. To extensively compare the influence of various conventional flotation reagents on biooxidation, bacterial activities of these microorganisms were studied in the presence of different collectors and frothers with the same concentration $(0.01 \% w / v)$ by fundamental measurement techniques. Results indicated that, generally, the tested reagents have negative effect on the bacterial activities. These negative effects were stronger on biooxidation of $A$. ferrooxidans versus L. ferrooxidans. In general, the negative effects of collectors on both bacteria can be deduced to be in the following order: KIPX $>$ Aero $>\mathrm{NaEX}>\mathrm{KIBX}>\mathrm{KAX}$. For the frothers, MIBC was more toxic than PO. Results demonstrated the dominance of L. ferrooxidans over A. ferrooxidans during the growth and bacterial activities in the presence of various chemical reagents. These results can be used for selection of reagents in the initial stage of designing flotation separation methods.

Acknowledgments: Authors would like to appreciate all supports and providing microorganisms for this investigation from the Center of Research and Development in Sarcheshmeh mine, Kerman, Iran. Also we would like to thank Ali Rezai, Ali Allahverdi, and Hossayni for their assistance in the mineral processing laboratory at University of Tehran, and Gharban Zadeh for the AAS analyses in the geochemistry laboratory at University of Tehran.

Author Contributions: M. Jafari, S.Z. Shafaei, and H. Abdollahi conceived and designed the experiments; M. Jafari performed the experiments; S. Chehreh Chelgani, S.Z. Shafaei and M. Gharabaghi analyzed the data; S.Z. Shafaei contributed analyses and assessments; S. Chehreh Chelgani and M. Jafari wrote the paper.

Conflicts of Interest: The authors declare no conflict of interest.

\section{References}

1. Dehghan, R.; Dianati, M. The effects of $\mathrm{Pb}-\mathrm{Zn}$ flotation reagents on the bioleaching process by mesophilic bacteria. Int. J. Miner. Process. 2015, 143, 80-86. [CrossRef]

2. Deo, N.; Natarajan, K. Biological removal of some flotation collector reagents from aqueous solutions and mineral surfaces. Miner. Eng. 1998, 11, 717-738. [CrossRef] 
3. Dong, Y.; Lin, H. Influences of flotation reagents on bioleaching of chalcopyrite by Acidithiobacillus ferrooxidans. Miner. Eng. 2012, 32, 27-29. [CrossRef]

4. Guo, Z.; Yao, J.; Wang, F.; Yuan, Z.; Bararunyeretse, P.; Zhao, Y. Effect of three typical sulfide mineral flotation collectors on soil microbial activity. Environ. Sci. Pollut. Res. 2016, 23, 7425-7436. [CrossRef] [PubMed]

5. Okibe, N.; Johnson, D.B. Toxicity of flotation reagents to moderately thermophilic bioleaching microorganisms. Biotechnol. Lett. 2002, 24, 2011-2016. [CrossRef]

6. Dew, D.W.; Lawson, E.N.; Broadhurst, J.L. The biox ${ }^{\circledR}$ process for biooxidation of gold-bearing ores or concentrates. In Biomining; Rawlings, D.E., Ed.; Springer: Berlin, Germany, 1997; pp. 45-80.

7. Tuovinen, O.H. Inhibition of Thiobacillus ferrooxidans by mineral flotation reagents. Appl. Microbiol. Biotechnol. 1978, 5, 301-304. [CrossRef]

8. Ballester, A.; Blázquez, M.; González, F.; Muñoz, J. New information on the sphalerite bioleaching mechanism at low and high temperature. Hydrometallurgy 2003, 71, 57-66.

9. Deveci, H.; Akcil, A.; Alp, I. Bioleaching of complex zinc sulphides using mesophilic and thermophilic bacteria: Comparative importance of $\mathrm{pH}$ and iron. Hydrometallurgy 2004, 73, 293-303. [CrossRef]

10. Escobar, B.; Quiroz, L.; Vargas, T. Effect of flotation and solvent extraction reagents on the bioleaching of a copper concentrate with Sulfolobus metallicus. Adv. Mater. Res. 2009, 71, 421-424. [CrossRef]

11. Lundgren, D.; Silver, M. Ore leaching by bacteria. Annu. Rev. Microbiol. 1980, 34, 263-283. [CrossRef] [PubMed]

12. Brierley, C.L. Microbiological mining. Sci. Am. 1982, 247, 44-53. [CrossRef]

13. Kelly, D.P.; Wood, A.P. Reclassification of some species of Thiobacillus to the newly designated genera Acidithiobacillus gen. Nov., halothiobacillus gen. Nov. and thermithiobacillus gen. Nov. Int. J. Syst. Evol. Microbiol. 2000, 50, 511-516. [CrossRef] [PubMed]

14. Temple, K.L.; Colmer, A.R. The autotrophic oxidation of iron by a new bacterium: Thiobacillus ferrooxidans. J. Bacteriol. 1951, 62, 605-611. [PubMed]

15. Rawlings, D.; Tributsch, H.; Hansford, G. Reasons why 'Leptospirillum'-like species rather than Thiobacillus ferrooxidans are the dominant iron-oxidizing bacteria in many commercial processes for the biooxidation of pyrite and related ores. Microbiology 1999, 145, 5-13. [CrossRef] [PubMed]

16. Dave, S.R. Selection of Leptospirillum ferrooxidans SRPCBL and development for enhanced ferric regeneration in stirred tank and airlift column reactor. Bioresour. Technol. 2008, 99, 7803-7806. [CrossRef] [PubMed]

17. Mason, L.J.; Rice, N.M. The adaptation of Thiobacillus ferrooxidans for the treatment of nickel-iron sulphide concentrates. Miner. Eng. 2002, 15, 795-808. [CrossRef]

18. Silverman, M.P.; Lundgren, D.G. Studies on the chemoautotrophic iron bacterium ferrobacillus ferrooxidans: I. An improved medium and a harvesting procedure for securing high cell yields. J. Bacteriol. 1959, 77, 642-647. [PubMed]

19. Rodrigues, M.L.; Leão, V.A.; Gomes, O.; Lambert, F.; Bastin, D.; Gaydardzhiev, S. Copper extraction from coarsely ground printed circuit boards using moderate thermophilic bacteria in a rotating-drum reactor. Waste Manag. 2015, 41, 148-158. [CrossRef] [PubMed]

20. Rodrigues, M.L.; Lopes, K.C.; Leôncio, H.C.; Silva, L.A.; Leão, V.A. Bioleaching of fluoride-bearing secondary copper sulphides: Column experiments with Acidithiobacillus ferrooxidans. Chem. Eng. J. 2016, 284, 1279-1286. [CrossRef]

21. Veloso, T.C.; Sicupira, L.C.; Rodrigues, I.C.; Silva, L.A.; Leão, V.A. The effects of fluoride and aluminum ions on ferrous-iron oxidation and copper sulfide bioleaching with Sulfobacillus thermosulfidooxidans. Biochem. Eng. J. 2012, 62, 48-55. [CrossRef]

22. Iwasaki, I.; Cooke, S. Dissociation constant of xanthic acid as determined by spectrophotometric method. J. Phys. Chem. 1959, 63, 1321-1322. [CrossRef]

23. Pomianowski, A.; Leja, J. Spectrophotometric study of xanthate and dixanthogen solutions. Can. J. Chem. 1963, 41, 2219-2230. [CrossRef]

24. Jones, M.; Woodcock, J. Decomposition of alkyl dixanthogens in aqueous solutions. Int. J. Miner. Process. 1983, 10, 1-24. [CrossRef]

25. Puhakka, J.; Tuovinen, O.H. Effect of organic compounds on the microbiological leaching of a complex sulphide ore material. World J. Appl. Microbiol. Biotechnol. 1987, 3, 429-436. [CrossRef]

26. Loon, H.Y.; Madgwick, J. The effect of xanthate floatation reagents on bacterial leaching of chalcopyrite by Thiobacillus ferrooxidans. Biotechnol. Lett. 1995, 17, 997-1000. [CrossRef] 
27. Sun, Z.; Forsling, W. The degradation kinetics of ethyl-xanthate as a function of $\mathrm{pH}$ in aqueous solution. Miner. Eng. 1997, 10, 389-400. [CrossRef]

28. Liu, Y.G.; Zhou, M.; Zeng, G.M.; Li, X.; Xu, W.H.; Fan, T. Effect of solids concentration on removal of heavy metals from mine tailings via bioleaching. J. Hazard. Mater. 2007, 141, 202-208. [CrossRef] [PubMed]

29. Zhang, C.G.; Xia, J.L.; Zhang, R.Y.; Peng, A.A.; Nie, Z.Y.; Qiu, G.Z. Comparative study on effects of tween- 80 and sodium isobutyl-xanthate on growth and sulfur-oxidizing activities of Acidithiobacillus allbertensis by-05. Trans. Nonferr. Met. Soc. China 2008, 18, 1003-1007. [CrossRef]

30. Rawlings, D.E. Characteristics and adaptability of iron-and sulfur-oxidizing microorganisms used for the recovery of metals from minerals and their concentrates. Microb. Cell Fact. 2005, 4, 1-15. [CrossRef] [PubMed]

31. Norris, P. Iron and mineral oxidation with Leptospirillum-like bacteria. In Recent Progress in Biohydrometallurgy; Rossi, G., Torma, A.E., Eds.; Associazione Mineraria Sarda: Iglesias, Italy, 1983; pp. 83-96.

32. Sand, W.; Rohde, K.; Sobotke, B.; Zenneck, C. Evaluation of Leptospirillum ferrooxidans for leaching. Appl. Environ. Microbiol. 1992, 58, 85-92. [PubMed]

33. Hojjati, H.; Penev, K.; Pupkevich, V.R.; Karamanev, D.G. Modeling, simulation, and optimization of hybrid $\mathrm{Fe}(\mathrm{II}) / \mathrm{Fe}(\mathrm{III})$ redox flow fuel cell system. AIChE J. 2013, 59, 1844-1854. [CrossRef]

34. Boon, M.; Heijnen, J. Gas-liquid mass transfer phenomena in bio-oxidation experiments of sulphide minerals: A critical review of literature data. Hydrometallurgy 1998, 48, 187-204. [CrossRef]

35. Deveci, H.; Akcil, A.; Alp, I. Parameters for control and optimization of bioleaching of sulfide minerals. In Proceedings of the Materials Science and Technology Symposium: Process Control and Optimization in Ferrous and Non Ferrous Industry, Chicago, IL, USA, 9-12 November 2003; pp. 77-90.

36. Hulme, M.; Stranks, D. Induction and the regulation of production of cellulase by fungi. Nature 1970, 226, 469-470. [CrossRef] [PubMed]

37. Torma, A.E.; Gabra, G.; Guay, R.; Silver, M. Effects of surface active agents on the oxidation of chalcopyrite by Thiobacillus ferrooxidans. Hydrometallurgy 1976, 1, 301-309. [CrossRef]

38. Dopson, M.; Sundkvist, J.E.; Lindström, E.B. Toxicity of metal extraction and flotation chemicals to Sulfolobus metallicus and chalcopyrite bioleaching. Hydrometallurgy 2006, 81, 205-213. [CrossRef]

39. Hallmann, R.; Friedrich, A.; Koops, H.P.; Pommerening-Röser, A.; Rohde, K.; Zenneck, C.; Sand, W. Physiological characteristics of Thiobacillus ferrooxidans and Leptospirillum ferrooxidans and physicochemical factors influence microbial metal leaching. Geomicrobiol. J. 1992, 10, 193-206. [CrossRef]

40. Chowdhury, F.; Ojumu, T. Investigation of ferrous-iron biooxidation kinetics by Leptospirillum ferriphilum in a novel packed-column bioreactor: Effects of temperature and jarosite accumulation. Hydrometallurgy 2014, 141, 36-42. [CrossRef]

41. Yu, R.; Jing, L.; An, C.; Zhong, D.; Qian, L.; Qin, W.; Qiu, G.; Gu, G. Interaction mechanism of $\mathrm{Cu}^{2+}$, $\mathrm{Fe}^{3+}$ ions and extracellular polymeric substances during bioleaching chalcopyrite by Acidithiobacillus ferrooxidans ACTT2370. Trans. Nonferr. Met. Soc. China 2013, 23, 231-236. [CrossRef]

42. Curutchet, G.; Pogliani, C.; Donati, E.; Tedesco, P. Effect of iron (III) and its hydrolysis products (jarosites) on Thiobacillus ferrooxidans growth and on bacterial leaching. Biotechnol. Lett. 1992, 14, 329-334. [CrossRef]

43. Brierley, C.; Rawlings, D. Theory, microbes and industrial processes. In Biomining; Rawlings, D.E., Ed.; Springer: Berlin, Germany, 1997.

44. Norris, P.R.; Barr, D.W.; Hinson, D. Iron and mineral oxidation by acidophilic bacteria: Affinities for iron and attachment to pyrite. In Biohydrometallurgy: Proceedings of the International Symposium; Norris, P.R., Kelly, D.P., Eds.; Antony Rowe Ltd.: Chippenham, UK, 1987; pp. 43-59.

(C) 2016 by the authors; licensee MDPI, Basel, Switzerland. This article is an open access article distributed under the terms and conditions of the Creative Commons Attribution (CC-BY) license (http://creativecommons.org/licenses/by/4.0/). 